Tér és Társadalom 23. évf. 2009/3. 97-109. p.

Tér és Társadalom

XXIII. évf. 2009

3: $97-171$

\title{
GYORS TÉNYKÉP
}

\section{VÁROSOK \\ EGYETEMISTÁK MENTÁLIS TÉRKÉPEIN}

\author{
(Some Hungarian Cities by the Aspect of Students)
}

\author{
BALOGH ANDRÁS - BAJMÓCY PÉTER
}

Kulcsszavak:

kérdöív mentális térkép rang-módszer magyar városok regionális különbségek

Tanulmányunk öt egyetem hallgatóinak mentális térképei alapján mutatja be 60 magyarországi város fejlettség-, illetve méretbeli különbségeit. Azokat a különbségeket tehát, amelyek nem valós adatokban, hanem a fejekben realizálódnak. Vizsgáltuk, hogy a különbözö felsöoktatási intézményekben tamulók számára $a z$ ország mely városai és milyen vonatkozásban szimpatikusak, illetve, mely településekröl alakult $k i$ bennük negativ vélemény. Kérdés, hogy az öt egyetem hallgatói hasonlóképpen itélik-e meg ugyanazokat a városokat, vagy e téren is fellelhetök eltérések? Vizsgálatunk az egyes városokra adott lakosságbecslések és a valós népességszámok közötti igen jelentös különbségek okait is igyekszik feltárni.

\section{Bevezetés}

Magyarországon a rendszerváltozás utáni időszakban a gazdaság területileg differenciált növekedési pályára állása a területi és települési egyenlőtlenségek fokozódását eredményezte (Enyedi 1996; Nemes Nagy 1997; Kolosi 2000; BajmócyBalogh 2002; Andorka 2003; Beluszky 2007). Megváltoztak a településközi kapcsolatok, új növekedési pólusok és depressziós övezetek jelentek meg. A társadalom válaszai a gazdasági változásokra igen sokrétủek voltak. Az átalakulás legfontosabb következménye az egyenlötlenségek növekedése volt, melyek legélesebben a jövedelmi különbségek és az életkörülmények területén mutatkoztak meg (Kolosi 2000; Andorka 2003). A társadalmi egyenlőtlenségek növekedése - annak területi és települési differenciáltsága miatt - alapjaiban változtatták meg az ország térszerkezetét. Közismertek ma már a nyugat-kelet, a föváros-vidék, a város-falu dichotómiák, s az is, hogy mindezek együtt teszik igazán mozaikossá Magyarország teruileti képét. Kérdés azonban, hogy a statisztikai adatok feldolgozásával igazolható különbségek hogyan jelennek meg a fejekben, vagyis, hogy az emberek mit gondolnak az ország kisebb-nagyobb, fejlettebb-elmaradottabb, nyugaton, avagy keleten fekvő városairól, milyen kép él bennük e településekröl.

A mentális térképezés hazai irodalma ma már igen jelentós, ám ezek legtöbbje vagy egy-egy településsel foglalkozik (Letenyei 2004; Perényi 2006; Boros 2007), vagy egy nagyobb térség mentális térképét kutatja, de csak egy szúk térbeli- 
társadalmi csoport - egy-egy egyetem, középiskola diákjai - szemszögéböl (KissBajmócy 1996; Michalkó 1998; Bajmócy 2005). A tudati képződmények elöhívására alapvetően két módszer közül választhatunk. Az egyik az ún. rajzos módszer, amely során a kísérletben részt vevö személyek maguk rajzolnak térképeket és a kutató ezeket hasonlítja össze (Lynch 1960). A másik lehetőség az ún „rang-módszer”. Ebben az esetben a kutató maga sorolja fel azokat az objektumokat, amelyekre kíváncsi, és a kísérleti személyeknek annyi a feladata, hogy egy megadott tulajdonság szempontjából rendezze ezeket az objektumokat (Gould-White 1968). Vizsgálatunkban e módszerhez folyamodtunk.

\section{A vizsgálatról}

Kutatásunk során egyetemisták mentális térképeire voltunk kíváncsiak, arra, hogyan ítélnek meg különböző hazai városokat. Öt felsőoktatási intézmény (Budapest ELTE, Szeged, Pécs, Szombathely, Nyíregyháza) 100-100 első, illetve másodéves földrajz szakos hallgatója vett részt a vizsgálatban, 2007 telén. A földrajz szakos hallgatók vélhetően több és pontosabb ismerettel rendelkeznek Magyarországról, mint a többiek, ugyanakkor közülük még senki sem vett részt Magyarország társadalomföldrajza kurzuson a kutatás időpontjáig, így ismereteik zömmel más, tanórán kívüli forrásból származnak. A vizsgálat egyik továbblépési lehetősége annak kiterjesztése más, nem földrajz szakos hallgatók körére.

A hallgatóknak egy négy kérdéscsoportból álló kérdőívet kellett kitölteniük. Az első feladat során 60 hazai várost kellett szimpátia alapján értékelniük 1-tỏl 6-ig, ahol az 1-es a legkevésbé, a 6-os a leginkább szimpatikus településeket jelentette. A hatfokozatú osztályozás azért tűnt megfelelőnek, mivel egy korábbi vizsgálat tapasztalatai azt mutatták, hogy a relatíve ismeretlen városokat a hallgatók hajlamosak közepes értékkel osztályozni (Bajmócy 2005). A hatfokú skála esetében ugyanakkor nincs lehetőség a medián kiválasztására, mindenképp dönteni kell pozitív vagy negatív irányban.

A vizsgálatban részt vevő 60 település tartalmazta az összes megyeszékhelyet, megyei jogú várost, ezen kívül megyénként legalább még egy várost (1. táblázat). A legnépesebb városok mellett számos, speciális funkcióval rendelkezỏ kisebb város (ipari, turisztikai), valamint néhány „egyszerủ kisváros” is bekerült a vizsgálati körbe. A vizsgált települések területi elhelyezkedése is egyenletes, 24 dunántúli, 29 Dunától keletre lévő s hét Pest megyei (Budapesttel) került bele a kutatásba. A kérdöíven a városok sorrendje véletlenszerü volt.

A második és harmadik feladat során a hallgatóknak ki kellett választani a felsorolt 60 település közül az általuk legnagyobbnak (legnépesebbnek) és legkisebbnek tartott tizet-tizet és meg kellett becsülni e 10-10 város népességszámát. A negyedik feladat során öt tetszölegesen kiválasztott városról szöveges véleményt kellett írniuk a hallgatóknak. 
Balogh András - Bajmócy Péter : Városok egyetemisták mentális térképein.

Tér és Társadalom 23. évf. 2009/3. 97-109. p.

\section{TÁBLÁZAT}

A vizsgálatban részt vevö városok

(Cities Taking Part in Study)

\begin{tabular}{|c|c|c|c|c|c|}
\hline Település & Megye & Település & Megye & Település & Megye \\
\hline Pécs & Baranya & Székesfehérvár & Fejér & Cegléd & Pest \\
\hline Mohács & Baranya & Dunaújváros & Fejér & Vác & Pest \\
\hline Villány & Baranya & Győr & Gy.M.S. & Dunakeszi & Pest \\
\hline Komló & Baranya & Sopron & Gy.M.S. & Gödöllő & Pest \\
\hline Miskolc & B.A.Z. & Mosonmagyaróvár & Gy.M.S. & Kaposvár & Somogy \\
\hline Ózd & B.A.Z. & Debrecen & H.B & Siófok & Somogy \\
\hline Tiszaújváros & B.A.Z. & Hajdúszoboszló & H.B. & Nyíregyháza & Sz.Sz.B \\
\hline Sátoraljaủjhely & B.A.Z. & Hajdúböszörmény & H.B. & Mátészalka & Sz.Sz.B. \\
\hline Tokaj & B.A.Z. & Eger & Heves & Záhony & Sz.Sz.B. \\
\hline Budapest & - & Gyöngyös & Heves & Szekszárd & Tolna \\
\hline Békéscsaba & Békés & Szolnok & J.N.Sz. & Paks & Tolna \\
\hline Gyula & Békés & Martfü & J.N.Sz. & Szombathely & Vas \\
\hline Orosháza & Békés & Abádszalók & J.N.Sz. & Köszeg & Vas \\
\hline Kecskemét & $\begin{array}{l}\text { Bács- } \\
\text { Kiskun }\end{array}$ & Jászberény & J.N.Sz. & Körmend & Vas \\
\hline Baja & $\begin{array}{l}\text { Bács- } \\
\text { Kiskun }\end{array}$ & Tatabánya & K.E. & Veszprém & Veszprém \\
\hline Kalocsa & $\begin{array}{l}\text { Bács- } \\
\text { Kiskun }\end{array}$ & Esztergom & K.E. & Tapolca & Veszprém \\
\hline Kiskunfélegyháza & $\begin{array}{l}\text { Bács- } \\
\text { Kiskun }\end{array}$ & Salgótarján & Nógrád & Ajka & Veszprém \\
\hline Szeged & Csongrád & Balassagyarmat & Nógrád & Zalaegerszeg & Zala \\
\hline Hódmezővásárhely & Csongrád & Érd & Pest & Nagykanizsa & Zala \\
\hline Makó & Csongrád & Szentendre & Pest & Keszthely & Zala \\
\hline
\end{tabular}

Forrás: Saját szerkesztés.

\section{Eredmények}

Az egyes hallgatók a szimpátia tekintetében legmagasabb pontszámokat általában lakóhelyük, egyetemük, illetve azok környékén lévő településeknek adták. Összességében ugyanakkor a turisztikailag is jelentős városok kapták a legmagasabb pontszámokat, így Sopron, Pécs, Eger, Tokaj, Siófok pontszámai bizonyultak a legmagasabbnak (2. táblázat). A tradicionális turisztikai kis- és nagyvárosok mellett a borturizmus, a Balaton-part, a gyógyfürdők rendelkeztek a legmagasabb átlagértékekkel. A hallgatók számottevően segítették egyetemük városát, lényegesen magasabb pontokat adtak alma materük székhelyének, mint a többi egyetemista. Különösen számottevő ez Szeged esetében, ahol a szegedi egyetemisták átlaga csaknem egy teljes ponttal magasabb, mint a többieké. Kisebb mértékben hasonló a helyzet Budapest, Szombathely, Nyíregyháza és Pécs esetében is. 
Balogh András - Bajmócy Péter : Városok egyetemisták mentális térképein.

Tér és Társadalom 23. évf. 2009/3. 97-109. p.

100 Gyors ténykép

TÉT XXIII. évf. 2009

\section{3}

2. TÁBLÁZAT

A legnépszerübb városok öt egyetem hallgatoinak véleménye alapján

(The Most Popular Cities by the Students of 5 Universities)

\begin{tabular}{|c|c|c|c|c|c|c|c|c|}
\hline \multirow[b]{2}{*}{ Helyezés } & \multirow[b]{2}{*}{ Város } & \multirow{2}{*}{$\begin{array}{l}\text { Népesség- } \\
\text { szám } \\
\\
2007\end{array}$} & \multirow{2}{*}{$\begin{array}{c}\text { Osztályozás } \\
\text { (átlag) } \\
\tilde{y} \\
\tilde{y} \\
: 0\end{array}$} & \multicolumn{5}{|c|}{ Osztályozás (átlag) } \\
\hline & & & & 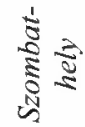 & $e^{y}$ & 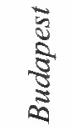 & 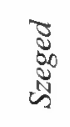 & 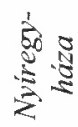 \\
\hline 1. & Sopron & 57210 & 5,07 & 4,90 & 4,94 & 5,38 & 5,16 & 4,99 \\
\hline 2. & Pécs & 156649 & 5,06 & 5,17 & 5,39 & 4,98 & 4,92 & 4,84 \\
\hline 3. & Eger & 56647 & 4,99 & 4,83 & 4,73 & 5,06 & 5,20 & 5,13 \\
\hline 4. & Tokaj & 4757 & 4,89 & 4,89 & 4,82 & 4,86 & 5,01 & 4,86 \\
\hline 5. & Szeged & 164883 & 4,86 & 4,61 & 4,63 & 4,69 & 5,63 & 4,74 \\
\hline 6. & Siófok & 23982 & 4,85 & 4,90 & 4,59 & 4,65 & 4,97 & 5,15 \\
\hline 7. & Debrecen & 204124 & 4,77 & 4,58 & 4,63 & 4,90 & 4,80 & 4,93 \\
\hline 8. & Keszthely & 21289 & 4,59 & 4,82 & 4,73 & 4,79 & 4,42 & 4,17 \\
\hline 9. & Esztergom & 30261 & 4,58 & 4,37 & 4,51 & 4,86 & 4,72 & 4,46 \\
\hline 10. & Györ & 128265 & 4,57 & 5,01 & 4,14 & 4,68 & 4,57 & 4,46 \\
\hline 11. & Hajdúszoboszló & 23383 & 4,52 & 4,31 & 4,21 & 4,44 & 4,64 & 5,00 \\
\hline 12. & Villány & 2580 & 4,51 & 4,49 & 4,61 & 4,50 & 4,69 & 4,26 \\
\hline 13. & Veszprém & 62023 & 4,37 & 4,51 & 4,58 & 4,52 & 4,29 & 3,95 \\
\hline 14. & Szentendre & 24620 & 4,28 & 3,98 & 3,89 & 4,72 & 4,49 & 4,31 \\
\hline 15. & Kőszeg & 12016 & 4,24 & 4,17 & 4,38 & 4,78 & 4,14 & 3,70 \\
\hline
\end{tabular}

Forrás: Saját számítás.

Amíg a legnépszerübb városok között a dunántúliak dominálnak, addig a legkevésbé népszerüek között Észak-Magyarország, Észak-Alföld és Dél-Dunántúl települései emelkednek ki (3. táblázat). Számos iparváros, egykori mezöváros és a periférikus térségek kisvárosai igen alacsony pontszámokat kaptak.

A lista két szélső végén Sopron és Ózd található, jól reprezentálva napjaink gazdasági-társadalmi sikereit, illetve kudarcait. A méret ez esetben nem lényeg, a legszimpatikusabb és a legkevésbé szimpatikus városok között egyaránt találunk kicsiket és nagyokat is. Vélhetően más lenne a helyzet, ha a szimpátia mellett a költözési szándékot is néznénk. Érdekes Budapest helye a népszerüségi listán. A főváros jelenleg a középmezőny első felében foglal helyet (23.), ugyanakkor egy korábbi vizsgálat során még a harmadik legrosszabb helyet kapta Ózd és Salgótarján után (Bajmócy 2005). Növekvő népszerủségének elsősorban gazdasági okai lehetnek, s ez a reálfolyamatokban is megfigyelhető: a főváros bỏ évtizedes népességfogyása lényegében leállt az elmúlt években, elsősorban a vidékröl felköltöző - többek között friss diplomás - népességnek köszönhetöen. 
Balogh András - Bajmócy Péter : Városok egyetemisták mentális térképein.

Tér és Társadalom 23. évf. 2009/3. 97-109. p.

TÉT XXIII. évf. 2009 『 3

Gyors ténykép

101

3. TÁBLÁZAT

A legnépszerütlenebb városok öt egyetem hallgatóinak véleménye alapján

(The Least Popular Cities by the Students of 5 Universities)

\begin{tabular}{|c|c|c|c|c|c|c|c|c|}
\hline \multirow[b]{2}{*}{ Helyezés } & \multirow[b]{2}{*}{ Város } & \multirow{2}{*}{$\begin{array}{c}\text { Népesség- } \\
\text { szám }\end{array}$} & \multirow{2}{*}{ 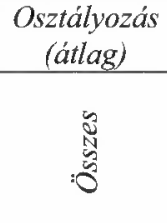 } & \multicolumn{5}{|c|}{ Osztályozás (átlag) } \\
\hline & & & & 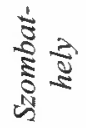 & $\begin{array}{l}\tilde{y} \\
\tilde{Q}\end{array}$ & $\frac{\sqrt[3]{3}}{\frac{5}{5}}$ & 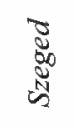 & 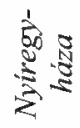 \\
\hline 60. & Ózd & 37040 & 2,03 & 2,02 & 1,90 & 1,81 & 1,97 & 2,46 \\
\hline 59. & Salgótarján & 39640 & 2,22 & 2,29 & 2,06 & 2,15 & 2,07 & 2,53 \\
\hline 58. & Záhony & 4443 & 2,64 & 2,54 & 2,46 & 2,56 & 2,59 & 3,02 \\
\hline 57. & Mátészalka & 17712 & 2,68 & 2,68 & 2,61 & 2,72 & 2,63 & 2,77 \\
\hline 56. & Paks & 20204 & 2,78 & 2,79 & 2,93 & 2,70 & 2,78 & 2,71 \\
\hline 55. & Komló & 26465 & 2,78 & 3,01 & 2,54 & 2,73 & 2,77 & 2,87 \\
\hline 54. & Martfü & 6997 & 2,85 & 2,97 & 2,69 & 2,94 & 2,99 & 2,66 \\
\hline 53. & Balassagyarmat & 16922 & 2,87 & 3,04 & 2,87 & 2,88 & 2,77 & 2,80 \\
\hline 52. & Körmend & 12186 & 2,94 & 3,14 & 2,97 & 3,04 & 2,80 & 2,76 \\
\hline 51. & Hajdúböszörmény & 31910 & 3,03 & 2,92 & 2,86 & 3,20 & 3,00 & 3,17 \\
\hline 50. & Jászberény & 27386 & 3,03 & 2,94 & 2,96 & 3,22 & 3,07 & 2,97 \\
\hline 49. & Cegléd & 38476 & 3,07 & 2,96 & 2,96 & 3,35 & 3,11 & 2,99 \\
\hline 48. & Nagykanizsa & 50823 & 3,08 & 3,30 & 3,13 & 3,14 & 3,04 & 2,78 \\
\hline 47. & Kiskunfélegyháza & 30946 & 3,09 & 3,05 & 2,99 & 3,11 & 3,34 & 2,99 \\
\hline 46. & Tatabánya & 70541 & 3,12 & 3,13 & 3,01 & 3,22 & 3,07 & 3,15 \\
\hline
\end{tabular}

Forrás: Saját számítás.

A regionális különbségek az ország különböző pontjairól nézve is mások. A föváros megítélése a budapesti hallgatók esetében a legkedvezőbb, igaz, hogy így is csak a népszerüségi lista 18. helyét foglalja el. Az ELTE-n végzett felmérés szerint a legalacsonyabb pontátlaggal rendelkező települések egyrészt Észak-Magyarországról (Balassagyarmat, Salgótarján, Ózd, Miskolc, Tiszaújváros, Sátoraljaújhely) és Észak-Alföldről (Záhony, Mátészalka) kerültek ki, másrészt fóképp a Budapesttől délre fekvő területekről (Dunaújváros, Paks, Kiskunfélegyháza, Martfü). Azok a városok, amelyek a legmagasabb pontszámokat kapták, a Dunántúl északi, határhoz közel fekvő részein fekszenek (Esztergom, Győr, Sopron, Kőszeg), vagy a Balaton közelében (Veszprém, Siófok, Keszthely), illetve a nagyobb lélekszámú települések közé tartoznak, mint Pécs, Szeged, Debrecen (1. ábra).

Szombathelyről nézve a 15 legnépszerübb városból 10 dunántúli és mindössze 5 fekszik az ország keleti felében (Debrecen, Hajdúszoboszló, Szeged, Eger és Tokaj), ugyanakkor a 15 legalacsonyabb pontszámúból 13 található a Duna vonalától keletre (a két dunántúli Paks és Komló). Maga Szombathely a szombathelyiek szerint a legkedveltebb város: a 8. helyen áll az összesített rangsorban (2. ábra). 
Balogh András - Bajmócy Péter : Városok egyetemisták mentális térképein.

Tér és Társadalom 23. évf. 2009/3. 97-109. p.

\section{1. ÁBRA}

A 15 legnépszerübb, illetve legnépszerütlenebb város a budapesti hallgatók szerint (The Most and Least Popular Cities by the Students of Budapest)

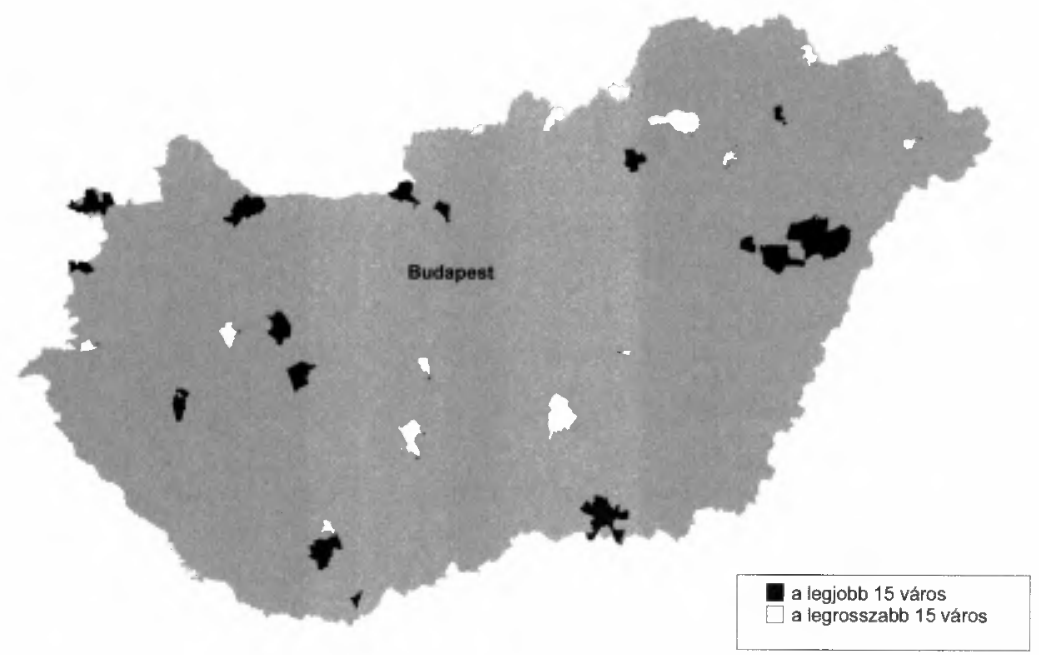

Forrás: Saját számítás alapján szerkesztette Balogh A.

\section{2. ÁBRA}

A 15 legnépszerübb, illetve legnépszerütlenebb város a szombathelyi hallgatók szerint (The Most and Least Popular Cities by the Students of Szombathely)

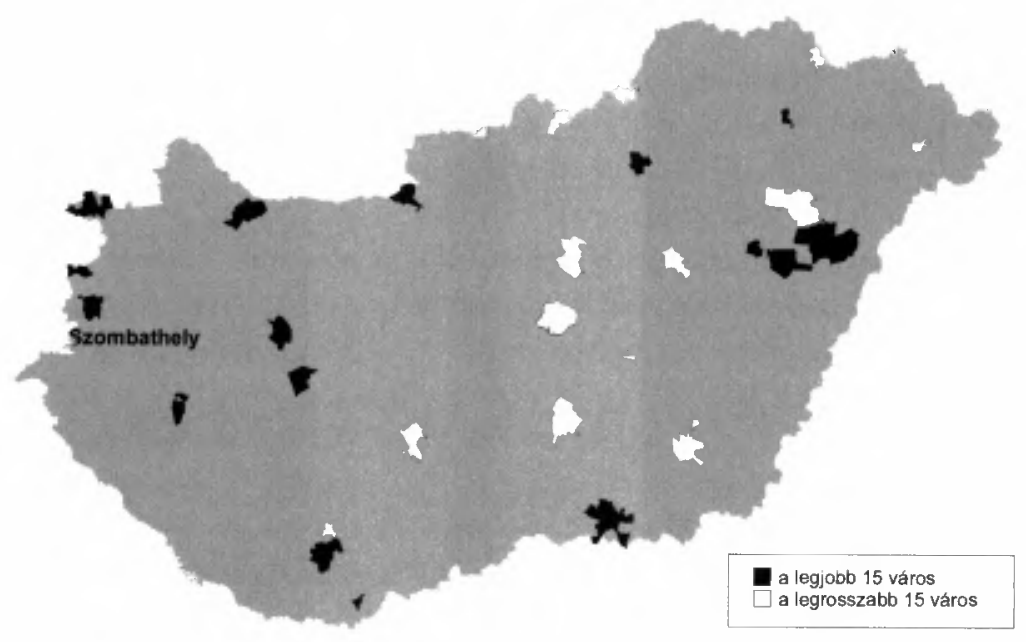

Forrás: Saját számítás alapján szerkesztette Balogh A. 
A pécsi egyetemisták véleménye nagyon közel áll a szombathelyiekéhez. Szintén dunántúli dominancia jellemzi a magas pontszámot elért városokat, és alföldi, észak-magyarországi a legalacsonyabb értékeket kapott településeket (3. ábra). Ami különbség: Budapest megítélése Szombathelyről jóval kedvezőbb, mint a baranyai nagyvárosból.

\section{3. ÁBRA}

A 15 legnépszerübb, illetve legnépszerütlenebb város a pécsi hallgatók szerint (The Most and Least Popular Cities by the Students of Pécs)

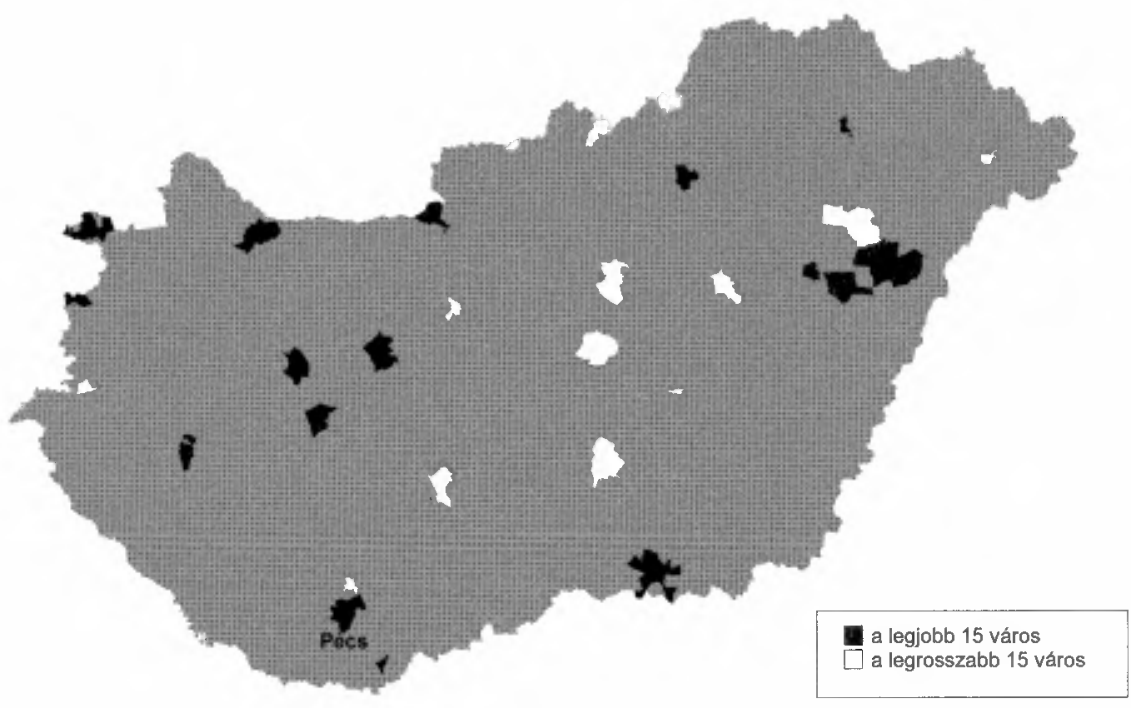

Forrás: Saját számítás alapján szerkesztette Balogh $\mathrm{A}$.

Ahogy nagyfokú hasonlóság mutatható ki Szombathely és Pécs között, szintén közel azonos eredményeket hoztak a két alföldi - szegedi és nyíregyházi - felsőoktatási intézményben kitöltött kérdőívek. Nyíregyházáról és Szegedről nézve a kép sokkal kevertebb, mint Szombathelyről és Pécsről: több keleti fekvésủ település is a jók közé került, s több dunántúli (Körmend, Ajka, Paks, Nagykanizsa) van a legellenszenvesebb városok között (4., 5. ábra). Debrecen, Hajdúszoboszló vagy Záhony megítélése pedig lényegesen kedvezőbb Nyíregyházáról és Szegedröl. Ebben az esetben is elsősorban a föváros megítélésében van számottevő eltérés: A nyíregyházi föiskola hallgatói esetében Budapest a 21. legkedveltebb város a 60-as listából, a szegediek véleménye ugyanakkor ennél jóval lesújtóbb: csupán a 43, hely jutott fơvárosunknak. (Budapest legrosszabb helyezését egyébként a szegedieknek „,köszönheti”.) Egymás városát is ellentmondásosan ítélték meg: Szeged mind a nyíregyháziak, mind a szegediek szerint nagyon kedvelt város (11., ill. 1. hely), Nyíregyházát azonban csak a nyíregyháziak szeretik, a szegediek kevésbé (3., ill. 42. hely). 
Balogh András - Bajmócy Péter : Városok egyetemisták mentális térképein.

Tér és Társadalom 23. évf. 2009/3. 97-109. p.

\section{4. ÁBRA}

A 15 legnépszerübb, illetve legnépszerütlenebb város a nyíregyházi hallgatók szerint (The Most and Least Popular Cities by the Students of Nyirregyháza)

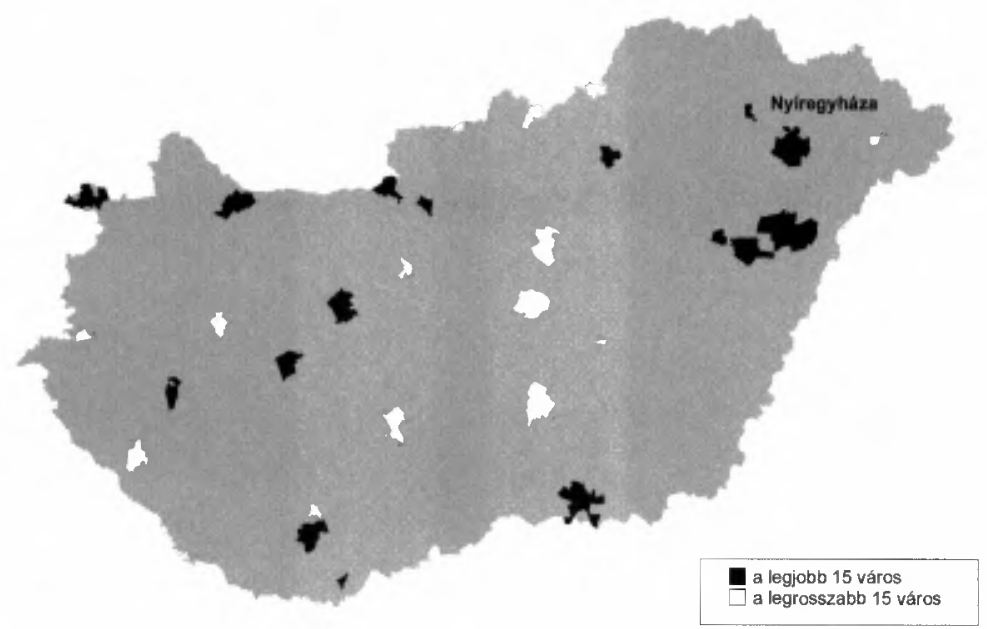

Forrás: Saját számítás alapján szerkesztette Balogh A.

\section{5. ÁBRA}

A 15 legnépszerübb, illetve legnépszerütlenebb város a szegedi hallgatók szerint

(The Most and Least Popular Cities by the Students of Szeged)

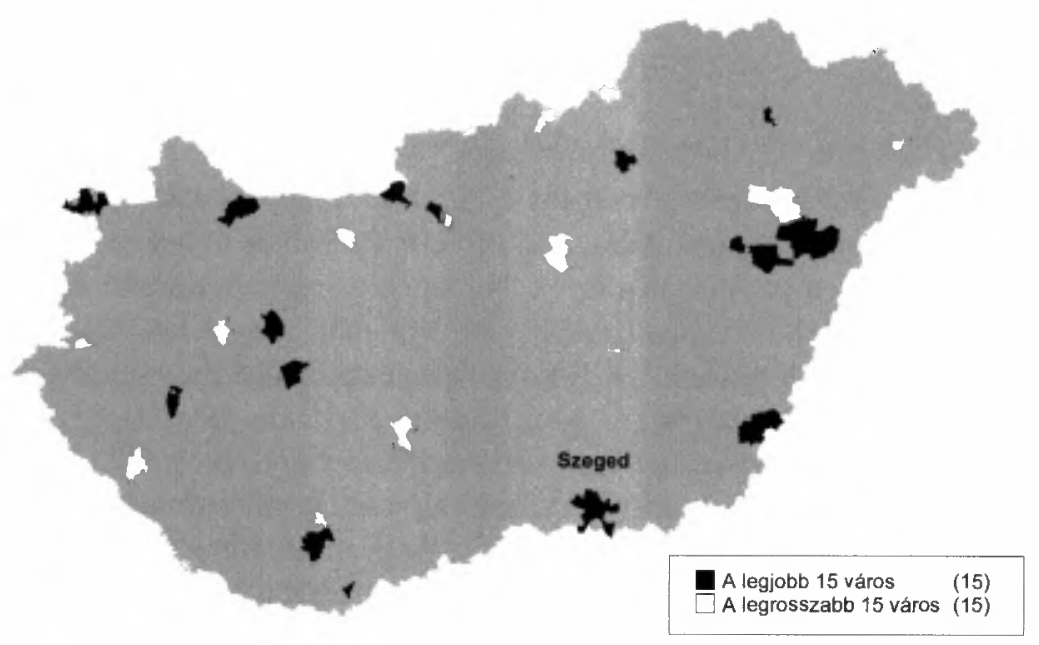

Forrás: Saját számítás alapján szerkesztette Balogh A. 
A második és harmadik kérdés során a tíz legnagyobb és legkisebb várost kellett kiválasztaniuk a hallgatóknak a felsoroltak közül, s népességszámukat is meg kellett becsülniük. Néhányan nem adtak értékelhető választ e kérdésre, így fordulhat elö, hogy csak a hallgatók 98\%-a vélte úgy, hogy Budapest a tíz legnagyobb között van. A válaszok szórása igen nagy volt, sem az átlaguk, sem a mediánjuk nem adott jól elemezhető értékeket, így arra koncentráltunk, hogy a válaszadók hány százaléka jelölte az egyes városokat a tíz legnagyobb és legkisebb közé (4., 5. táblázat).

\section{TÁBLÁZAT}

A vizsgálatban szereplö húsz legnagyobb város méret szerinti megitélése

az öt egyetem hallgatói szerint

(The Largest Cities in this Research and their Votes [\%] by the Hungarian University Students)

\begin{tabular}{clccc}
\hline Helyezés & \multicolumn{1}{c}{ Város } & $\begin{array}{c}\text { Népességszám } \\
(2007)\end{array}$ & $\begin{array}{c}\text { Nagynak } \\
\text { ítélt }(\%)\end{array}$ & $\begin{array}{c}\text { Kicsinek itélt } \\
(\%)\end{array}$ \\
\hline 1. & Budapest & 1696128 & 98 & 0 \\
2. & Debrecen & 204124 & 93 & 0 \\
3. & Miskolc & 172637 & 78 & 0 \\
4. & Szeged & 164883 & 82 & 0 \\
5. & Pécs & 156649 & 83 & 0 \\
6. & Gyỏr & 128265 & 77 & 0 \\
7. & Nyíregyháza & 116298 & 54 & 0 \\
8. & Kecskemét & 109847 & 46 & 1 \\
9. & Székesfehérvár & 101600 & 57 & 0 \\
10. & Szombathely & 79534 & 39 & 0 \\
11. & Szolnok & 75474 & 28 & 0 \\
12. & Tatabánya & 70541 & 12 & 4 \\
13. & Kaposvár & 67746 & 10 & 1 \\
14. & Békéscsaba & 65206 & 18 & 0 \\
15. & Érd & 62408 & 3 & 24 \\
16. & Veszprém & 62023 & 25 & 1 \\
17. & Zalaegerszeg & 61898 & 24 & 1 \\
18. & Sopron & 57210 & 29 & 2 \\
19. & Eger & 56647 & 22 & 4 \\
20. & Nagykanizsa & 50823 & 7 & 2 \\
\hline
\end{tabular}

Forrás: Saját számítás.

A népesebb városoknál érdekes Sopron helyzete, amely a valósnál lényegesen több voksot kapott (népszerủség, turizmus), valamint Nagykanizsa és különösen Érd, amelyek lényegesen kevesebbet. Érdet (karakter, speciális funkciók hiánya, alvóváros jelleg) a legkisebb tízbe lényegesen többen gondolták, mint a legnagyobbak közé. Nagykanizsa esetében vélhetően a kevésbé karakteres jelleg (és név?) lehet a kevés szavazat oka. A legkisebb városok között a helyzet bonyolultabb. A legtöbb kisvárost valóban inkább a kisebbek közé sorolták a hallgatók, de egyes karaktere- 
Balogh András - Bajmócy Péter : Városok egyetemisták mentális térképein.

Tér és Társadalom 23. évf. 2009/3. 97-109. p.

sebb kisvárosokat a valóságosnál nagyobbnak véltek. E karakter lehet a korábbi központi szerep (Balassagyarmat, Sátoraljaújhely), az ipar (Tiszaújváros, Paks) és a turizmus (Keszthely, Hajdúszoboszló, Siófok) is.

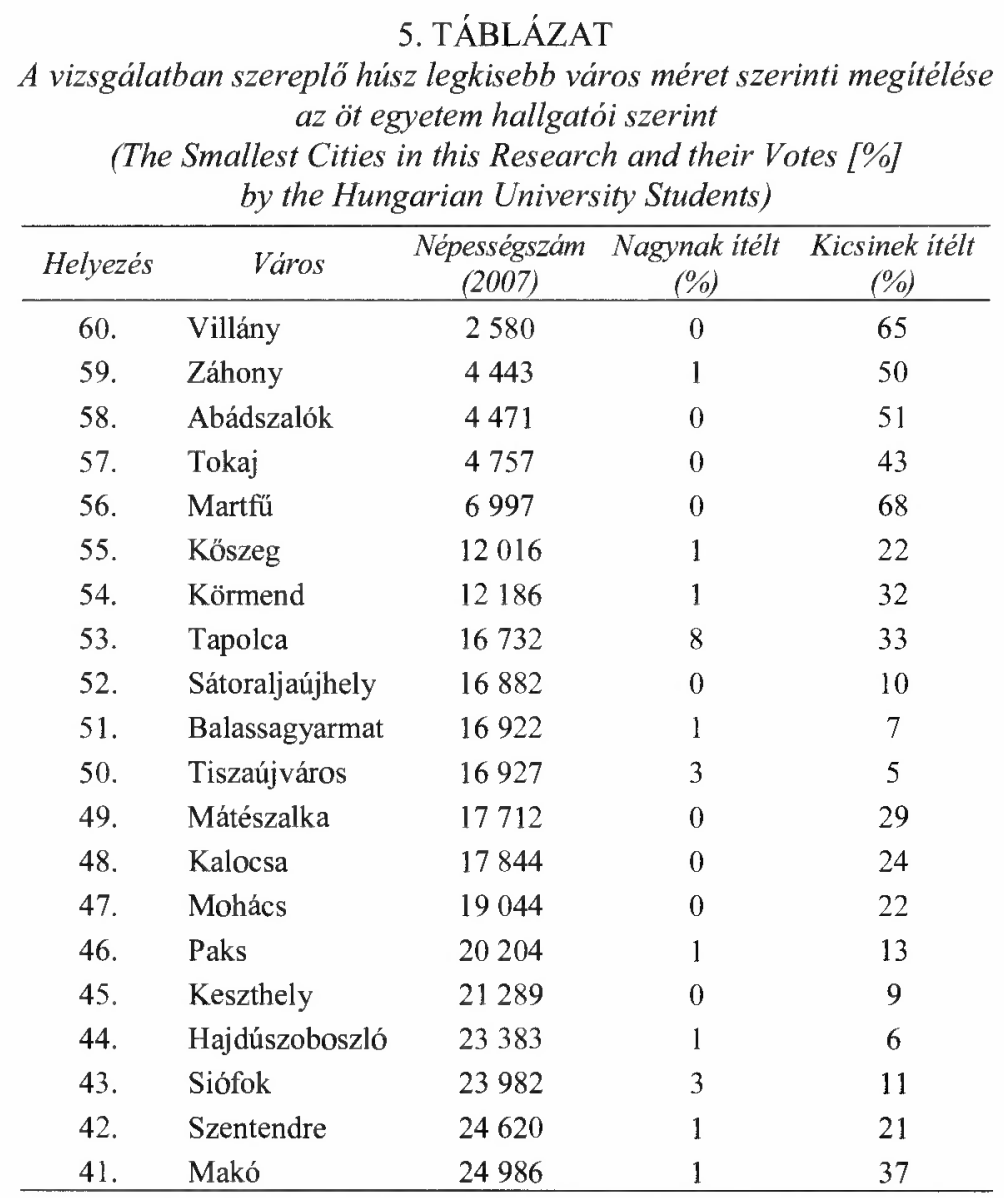

Forrás: Saját számítás.

$\mathrm{Az}$ utolsó feladatban a kérdöivet kitöltó hallgatóknak a megadott 60-as településlistából ki kellett választaniuk tetszőleges ötöt, és azokat pár mondatban jellemezniük. Általánosságban elmondható, hogy elsösorban a legnépesebb városok és a legfóbb turisztikai desztinációk kerültek kiválasztásra, elsö helyen Budapesttel (201 említés). A fỏvárost Szeged, Eger, Pécs, Tokaj, Siófok, Debrecen és Sopron követi (80-120 említés), azaz a településmérettel ellentétben a karakteres jellegnek e feladatnál már több szerepe van, mint az a korábbiakban látható volt. Az ez után következö települések köre (Györ, Miskolc, Esztergom, Villány, Paks, 45-60 jellemzés) még összetettebb, nagyvárosok mellett idegenforgalmi települések és egy iparváros is számos említést kapott. Gyakran írtak a hallgatók a saját felsőoktatási intézményüknek helyet adó településről is. (Pécs esetében ez ugyanakkora gyakori- 
sággal fordul elő, mint a fỏváros, a szegediek pedig másfélszer annyian választották Szegedet, mint Budapestet és háromszor annyian, mint az azt követő Egert, Siófokot és Villányt). További jellegzetesség, hogy az idegenforgalmi helyszínek említésekor a válaszok száma független a lélekszámtól.

Számos város ugyanakkor szinte egyetlen alkalommal sem került kiválasztásra. Ilyenek többek között Orosháza, Kiskunfélegyháza, Hajdúböszörmény, Jászberény, Mátészalka, Cegléd, Dunakeszi, Balassagyarmat, Sátoraljaújhely stb. Vagyis a kevésbé karakterisztikus települések, nagyrészt kisvárosok, amelyek zömében az Alföldön vagy Budapest közelében fekszenek. Szintén csak néhány (6-12) esetben választottak a hallgatók egyes megyeszékhelyeket, illetve megyei jogú városokat. Ezeket ugyan zömmel ismerik a hallgatók, de nem tartják annyira fontosnak e településeket, hogy az első ötben említsék. Ide tartozik Békéscsaba, Szolnok, Salgótarján, Tatabánya, Zalaegerszeg, Szekszárd, Kaposvár, Nagykanizsa és Hódmezővásárhely, azaz zömmel kisebb népességü és turisztikailag kevésbé kiemelkedő nagyvárosok. Ugyanebbe a csoportba tartozna Nyíregyháza is, ám mivel a nyíregyházi hallgatók számos esetben jelölték, így összességében több említést kapott az előzőeknél.

Az eddigiekből következik, hogy a hallgatók gyakran nem a megyeszékhelyet jellemezték legtöbbször az adott megyéböl, hanem egy másik, karakteresebbnek vélt települést (Siófok-Kaposvár, Paks-Szekszárd, Keszthely-Zalaegerszeg, SopronGyör, Esztergom-Tatabánya, Gyula-Békéscsaba, Tokaj-Miskolc, AbádszalókSzolnok, de a nyíregyháziak kivételével Záhony-Nyíregyháza is).

Az egyes egyetemek, föiskolák hallgatói eltérỏ intenzitással választottak bizonyos településeket. A hallgatók lakóhelyét, az egyetem települését, illetve a környékbeli kis- és nagyvárosokat lényegesen többször választották, mint a távolabbi településeket. Szegedet 56 szegedi egyetemista jellemezte, de csak 10-20 a másik négy intézményből. Hasonló a helyzet a többi egyetemi városban, Pécset 37 pécsi, 25 budapesti és szombathelyi, és mintegy 10 nyíregyházi és szegedi jellemezte. Budapest helyzete ugyanakkor sokkal stabilabb, minden egyetemről 35-45 említést kapott. Egyes városok, megyék ugyanakkor szinte csak a közelben lakók számára „léteznek”. Nyíregyháza csak öt, Mátészalka pedig egyetlen említést sem kapott a másik négy egyetem hallgatóitól. Dunakeszi, Szentendre, Vác említéseinek több mint fele budapestiektől származik, de Békéscsaba esetében a szegediek, Zalaegerszegnél pedig a szombathelyiek aránya szintén ennyire kiemelkedő. A kiválasztott városokra adott jellemzések alapján egyes megyék alig léteznek a megkérdezett egyetemisták körében. Ilyenek Fejér, Komárom-Esztergom, Zala, Jász-Nagykun-Szolnok, Békés és Szabolcs-Szatmár-Bereg (a válaszok 2-3\%-ával). E megyéket sokszor csak egyetlen város reprezentálja a hallgatók fejében (Esztergom, Keszthely, Gyula, Nyíregyháza). Ahol egyetlen ilyen karakterisztikus város sincs, az a megye gyakorlatilag „nincs” a hallgatók fejében. Ilyen Nógrád, amelynek vizsgálatba vont városai a közel kétezer hallgatói jellemzés közül mindössze 13 -at $(0,7 \%)$ mondhatnak magukénak.

Ami a néhány mondatos jellemzéseket illeti: a válaszok között, különösen a szegedi és budapesti hallgatók körében gyakoriak a „földrajzos jellegü" leírások (vaskohászat, atomerömủ, megyeszékhely, vasúti csomópont, cukorgyár stb.) 
Sokszor elöfordulnak ugyanakkor nem földrajzos szempontú leírások is. Ezek között személyes élmények (osztálykirándulás, nyaralás, tanulmányi versenyek, fellépések, koncertek), rokoni kapcsolatok, szórakozási lehetőségek is megjelennek. A média, de néha a szépirodalom által megismert helyszínek is jellemzőek. A személyes élmények közé sorolhatók a politikai irányú jellemzések (sztrájk, tüntetés, polgármesterek nevei, városok vélt politikai beállítottsága), illetve a sporttal kapcsolatos kötödések (kézilabda, kosárlabda, labdarúgó csapatok) is. Részben a földrajzos jellemzésekhez köthetők azok a leírások, amelyek város-, vagy területfejlesztési, területi elemzési jellegüek (iparváros, elmaradott település, fejlett gazdasággal rendelkezik, sokat fejlődött az elmúlt időben, recesszió jellemzi, „kelet kapuja” stb.). A legnagyobb csoportot azonban a települések idegenforgalmi vonzeröinek leírása adja, a legtöbb esetben helyesen. $\mathrm{E}$ helyes, valóságos válaszok aránya megközelíti a $100 \%$-ot, azaz a hallgatók olyan városokat választottak jellemzésre, amelyekröl biztos, sok esetben személyes tapasztalaton alapuló ismeretekkel rendelkeznek.

A hallgatók jellemzései a legtöbb esetben értéksemlegesek (mi van ott), néhány esetben azonban bizonyos pozitívnak vagy negatívnak vélt folyamatokat egy-egy várossal szimbolizálnak. Így a recesszióban lévő, etnikai problémákkal is küszködő iparvárost Miskolc és Ózd reprezentálja, a panellakótelepeket Miskolc és Dunaủjváros (illetve a lakóhelyhez közeli nagyváros) jeleníti meg. A Balatont, strandokat, bulikat, a nyarat Siófok reprezentálja. Keszthely azonban mintha nem is Balatonparti település lenne, csak egy város a Festetics-kastéllyal. Budapest megítélése a legkomplexebb, a sok lehetőség (szórakozás, vásárlás), az épített és természeti környezet szépségei mellett a városi lét negatívumai (kosz, zsúfoltság, nem közvetlen emberek) dominálnak. Ugyanakkor amíg a szegedi egyetemisták esetében a föváros negatív tulajdonságai dominálnak, addig a nyíregyháziak és szombathelyiek esetében a pozitívak hangsúlyosabbak, a budapestiek pedig a két folyamatot együtt látják. Számos esetben a városokat nem csak önmagában, hanem környékükkel együtt értékelték a hallgatók. A városok környékén lévő hegyek, természeti tájak sok esetben megjelentek, néha a távolabbiak is (Villány: Villányi-hegység és Mecsek, Eger: Szalajka-völgy). A lényeg legalább egy karakterisztikus tulajdonság, $\mathrm{s}$ ez esetben a tulajdonság milyensége nem számított, szinte bármi lehetett. (Makó: hagyma, Kalocsa: paprika, Paks: atomerömü, Záhony: átrakókörzet, Mohács: történelmi emlékhely, Tokaj, Villány, Eger: bor, Tokaj: Hegyalja Fesztivál, Ózd: lerobbant ipar, cigányság és munkanélküliség, Esztergom: bazilika, Siófok: strand, Martfü: Tisza cipö, Szeged: dóm és szép lányok.)

A kutatás legfontosabb eredményei az alábbiakban összegezhetők. Az egyetemisták fejében jelentős regionális különbségek léteznek, a hallgatók elsősorban a turisztikai, történelmi városokat tartják szimpatikusnak, regionálisan pedig a nyugati határ közelében lévőket, ugyanakkor a mezőgazdasági, ipari jellegüek, a kisvárosok zöme, avagy a keleti periférián lévők kevésbé szimpatikusak. A hallgatók lényegesen jobban ismerik és preferálják környéküket, különösen egyetemük városát. A népességbecslés esetében a valós méreten túl az ismertség, a karakterisztikus jelleg bizonyult a legfontosabbnak. Az információ lehet bármilyen, akár jó (turizmus, történelem), 
akár rossz (hanyatló ipar, vélt magas roma népesség), az eredmény ugyanaz, a lakosságbecslés magasabb a valósnál. Azokat a településeket, amelyekről a hallgatók alig rendelkeznek információkkal, általában kisebbnek vélték a valóságosnál. A legkarakterisztikusabb példákat a perifériák közép- és kisvárosai és a Budapesti agglomeráció nagy alvóvárosai adták ez utóbbi jelenségre. Amikor azonban csak néhány várost kell megnevezni, de azokat jellemezni is kell, a karakteres jelleg szerepe már kiemelkedő, az ismert, zömmel turisztikai vonatkozású városok kerülnek elötérbe. Az egyetemi városok hatása is eltérő az ott tanuló egyetemistákra. A legnagyobb hatást Pécs és elsősorban Szeged gyakorolja az ott tanulókra, minden tekintetben a szegedi egyetemisták a leginkább lokálpatrióták.

\section{Irodalom}

Andorka R. (2003) Bevezetés a szociológiába. Osiris Kiadó, Budapest.

Bajmócy P. (2005) Néhány Kárpát-medence-beli város megítélése egyetemisták körében. - Szónokyné Ancsin G. (szerk.) Hatơrok és Eurorégiók. SZTE Gazdaság- és Társadalomföldrajz Tanszék, Szeged. 359-364. o.

Bajmócy P.-Balogh A. (2002) Aprófalvas településállományunk differenciálódási folyamatai. - Földrajzi Értesitó. 3-4. 385-405. o.

Beluszky P. (1999) Magyarország településfóldrajza. Dialóg Campus Kiadó, Budapest-Pécs.

Beluszky P. (2007) Új irányok a magyarországi falufejlödésben. - Csapó T.-Kocsis Zs. (szerk.) A kistelepülések helyzete és településföldrajza Magyarországon. III. Településföldrajzi Konferencia, Szombathely. 5-14. o.

Boros, L. (2007) Szeged on University Students' Mental Maps. - Lehoczky, L.-Kalmár, L. (eds.) 6th International Conference of PhD Students. Natural Science, Miskolc. 45-50. o.

Enyedi Gy. (1996) Regionális folyamatok Magyarországon. Ember - település - régió. Budapest.

Gould, P.-White, R. (1968) The mental maps of British school-leavers. - Regional Studies. 2. 161-182. o.

Kiss J.-Bajmócy P. (1996) Egyetemi hallgatók mentális térképei Magyarországról. - Tér és Társadalom. 2-3. 55-68. o.

Kolosi T. (2000) A terhes babapiskóta. Osiris Kiadó, Budapest.

Koltai Z. (2007) A magyarországi városok versenyképességének vállalati megitélése. - Tér és Társadalom. 2. 23-42. o.

Letenyei L. (2004) Településkutatás. A települési és térségi tervezés társadalomtudományos alapozása. L'Harmattan Kiadó, Budapest. 147-185. o.

Lynch, K. (1960) The image of the City. MIT-Press, Cambridge/Mass.

Michalkó G. (1998) Mentális térképek a turizmus kutatásában. A magyar középiskolások Olaszország képe. - Tér és Társadalom. 1-2.112-129. o.

Nemes Nagy J. (1997) Régiók, regionalizmus. - Educatio. 3. 407-423. o.

Perényi R. (2006) Városi tér és hatalom: „utcapolitika” a századfordulós Budapesten. - Századvég. 39. 28-54. o. 